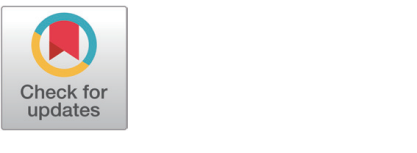

Received: May 6, 2021

Revised: July 21, 2021

Accepted: August 26, 2021

${ }^{+}$Corresponding author

Jung Sick Lee

Dept. of Aqualife Medicine, Chonnam

National University, Yeosu 59626, Korea

Tel: +82-61-659-7172

Fax: +82-61-659-7179

E-mail: ljs@jnu.ac.kr

Copyright $\odot 2021$ The Korean Society of Developmental Biology.

This is an Open Access article distributed under the terms of the Creative Commons Attribution Non-Commercial License (http://creativecommons.org/licenses/ by-nc/4.0/) which permits unrestricted non-commercial use, distribution, and reproduction in any medium, provided the original work is properly cited.

ORCID

Ji Sung Choi

https://orcid.org/0000-0002-8312-795X So Ryung Shin

https://orcid.org/0000-0002-2888-1378 Hyeon Jin Kim

https://orcid.org/0000-0001-9208-4616 Hyejin Kim

https://orcid.org/0000-0003-3853-0034 Yeonghye Kim

https://orcid.org/0000-0002-5927-0641

Jung Sick Lee

https://orcid.org/0000-0001-6292-328X

Conflict of interests

The authors declare no potential conflict of interest.

Acknowledgements

Not applicable.

\section{Gonadal Abnormality and Intersexuality of Oplegnathus fasciatus (Teleostei: Oplegnathidae) Collected from the Southern Coast of Korea: A Case Report}

\author{
Ji Sung Choi ${ }^{1}$, So Ryung Shin ${ }^{1}$, Hyeon Jin Kim ${ }^{1}$, Hyejin Kim², Yeonghye Kim³ , and \\ †Jung Sick Lee ${ }^{1}$ \\ 'Dept. of Aqualife Medicine, Chonnam National University, Yeosu 59626, Korea \\ ${ }^{2}$ Fisheries Seed and Breeding Research Institute, National Institute of Fisheries Science, Haenam 59002, Korea \\ ${ }^{3}$ Fisheries Resources Management Division, National Institute of Fisheries Science, Busan 46083, Korea
}

\begin{abstract}
We report on the gonadal structure abnormality and intersexuality found from a survey regarding the reproductive potential of the rock bream, Oplegnathus fasciatus, along the southern coast of Korea. In total, 448 samples were collected for histological analysis (total length $27.5 \pm 6.8 \mathrm{~cm}$; total weight $522.9 \pm 385.6 \mathrm{~g})$. The sex ratio (F:M) was 1:0.46 ( $\mathrm{n}=307: 141)$, with $68.5 \%$ being females. The frequency of oocyte atresia and ovarian neoplasm in the females was $85.3 \%$ and $21.5 \%$, respectively, and the frequency of testicular lobule and cyst deformation and testicular neoplasm in the males was $73.1 \%$ and $37.6 \%$, respectively. The scale formation in the ovary and testis was approximately $2.0 \%$ for both sexes. The intersexuality was $42.2 \%$, with the intersexuality among females being $49.5 \%$, which was significantly higher than that of males $(26.2 \%)$. Such findings indicate a negative impact on the reproductive output of the rock bream along the southern coast of Korea; however, a more detailed study is required to ascertain accurate causes.
\end{abstract}

Keywords: Oplegnathus fasciatus, Gonadal abnormality, Intersexuality

\section{INTRODUCTION}

The first phase of the ecological risk assessment procedure due to environmental factors is hazard identification (NRC, 1983). Among the biomarkers used for assessing ecotoxicity, reproductive biomarkers are an integral part of assessing long-term and continuous effects from environmental factors (Huggett et al., 1992; Schmitt et al., 2005). Histological biomarkers, including sex, stages of gonadal development, tumors, intersex, and atresia, are also an essential component for researching the reproductive health of fishes (Blazer, 2002; Kokokiris et al., 2005; Lee et al., 2010; Colin et al., 2016).

The rock bream, Oplegnathus fasciatus, is a teleost that belongs to Perciformes and Oplegnathidae. It is a coastal fish species that inhabits coastal waters of the South China Sea, Japan, and Korea (Kim et al., 2005). In Korea, the rock bream is a very important species for aquaculture and conservation of fishery resources. The rock bream is produced artificially from the hatched larvae to the early stage 
Authors' contributions

Conceptualization: Choi JS, Kim Y, Lee JS.

Data curation: Choi JS, Kim H.

Formal analysis: Shin SR, Kim HJ, Kim H.

Methodology: Lee JS.

Software: Shin SR, Kim HJ.

Validation: Kim Y, Lee JS.

Investigation: Choi JS, Shin SR, Kim HJ, Kim H.

Writing-original draft: Choi JS, Kim Y, Lee JS.

Writing-review \& editing: Shin SR, Kim HJ, Lee JS.

\section{Ethics approval}

This article does not require IRB/IACUC approval

because there are no human and animal

participants. before the juveniles are grown to approximately $5.0 \mathrm{~cm}$ in total length and ready to be released to the wild. Nearly 9 million fishes were released to the wild from 2012 to 2015 (FIRA, 2015). The present study aimed to investigate the gonad structural abnormality and intersexuality of the rock bream, O. fasciatus, inhabiting the southern coast of Korea, measured during a survey of their reproductive potential.

\section{MATERIALS \& METHODS}

\section{Specimens}

In total, 448 rock bream were used in the analysis with total length of $27.5 \pm 6.8 \mathrm{~cm}$ and total weight of $522.9 \pm 385.6 \mathrm{~g}$. The samples were collected using stow nets and trawl nets in waters near Sacheon, Mokpo, and Yeosu of Korea (Fig. 1).

\section{Histological analysis}

Five preparations of $1 \mathrm{~cm}^{2}$ area were analyzed from each individual after categorizing the gonads by fore, middle, and rear parts using the methods described by Lee et al. (2010). Each sample was fixed with $10 \%$ neutral buffered formalin and then dehydrated through an ethanol series (70\%-100\%). The tissues were embedded in paraplast (McCormick Scientific, St. Louis, MO). Embedded tissues were serially sectioned to a thickness of 4-6 $\mu \mathrm{m}$ using a microtome (RM2235, Leica, Germany). Samples were stained with Mayer's hematoxylin- $-0.5 \%$ eosin (H-E) stain and Masson's trichrome stain.

\section{Statistical analysis}

The chi-square test is conducted with SPSS 21.0 software (SPSS, Chicago, IL, USA) to verify the significant difference in sex ratio $(p<0.05)$.

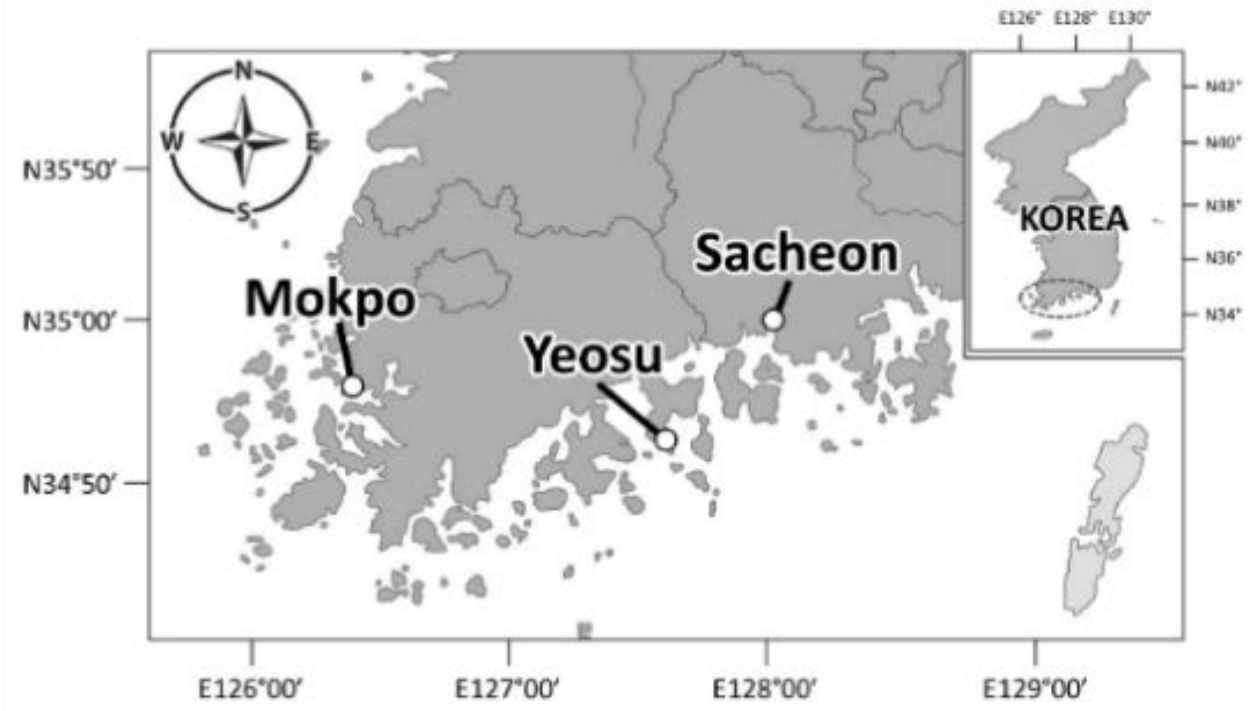

Fig. 1. Sampling area of the rock bream, Oplegnathus fasciatus. 


\section{RESULTS AND DISCUSSION}

\section{Sex ratio}

The sex ratio of $O$. fasciatus was 1:0.46, with 307 female specimens and 141 male specimens. Females made up approximately $68.5 \%$ of the entire sample, showing a significantly higher composition than that of the males $(p<0.05$; Table 1$)$.

\section{Ovarian structure abnormality}

\section{1) Oocyte atresia}

As oocyte atresia proceeds, the shape of the oocytes becomes irregular. We observed shrinking of the zona radiata and more eosinophilic reactions than those in the normal oocytes (Fig. 2A and B). Moreover, we identified the granulation of chromatin and the collapse of the nuclear membrane. A loss of eosinophilic yolk granules was observed in the cytoplasm. The yolk granules in the cortex and medulla were homogeneous, with the medulla found to be more basophilic in the $\mathrm{H}$-E stain than the cortex part (Fig. 2B and C). Oocyte atresia occurred in $85.3 \%$ of samples (Table 2).

\section{2) Ovarian neoplasm}

We could not morphologically identify the neoplasm in the form of nodules or tumors from the ovaries. However, histological analysis showed a cluster of multiple oocytes in different stages of development and a newly formed connective tissue layer outside the ovarian membrane (Fig. 3). The newly formed connective tissue layer turned blue in the Masson's trichrome stain (Fig. 3C). Oocytes and fatty tissues showed eosinophilic stainability and vacuoles in the H-E stain, respectively (Fig. 3B). The prevalence of ovarian neoplasm recorded was 21.5\% (Table 2).

Oocyte atresia is a normal phenomenon during the degeneration of oocytes after spawning in teleosts (Genten et al., 2009). Oocyte atresia has been reported as an endocrine disorder of female aquatic animals, which is inflicted on oogenesis owing to various environmental factors. The species currently affected include the common carp (Blazer, 2002); sole, Solea solea (Cuevas et al., 2015); brown bullhead, Ameiurus nebulosus; smallmouth bass, Micropterus dolomieu; yellow perch, Perca flavescens (Pinkney et al., 2017) and Mytilus trossulus (Smolarz et al., 2017). The histological properties

Table 1. Sex ratio of the rock bream, Oplegnathus fasciatus

\begin{tabular}{|c|c|c|c|c|c|c|}
\hline \multicolumn{3}{|c|}{ Specimen number } & \multicolumn{2}{|c|}{ Sax ratio } & \multirow{2}{*}{$\begin{array}{l}\text { Chi- } \\
\text { square }\end{array}$} & \multirow{2}{*}{$p$-value } \\
\hline Total & Female & Male & $\mathrm{F}: \mathrm{M}$ & $\mathrm{F} / \mathrm{F}+\mathrm{M}(\%)$ & & \\
\hline 448 & 307 & 141 & $1: 0.46$ & 68.5 & 61.509 & 0.000 \\
\hline
\end{tabular}

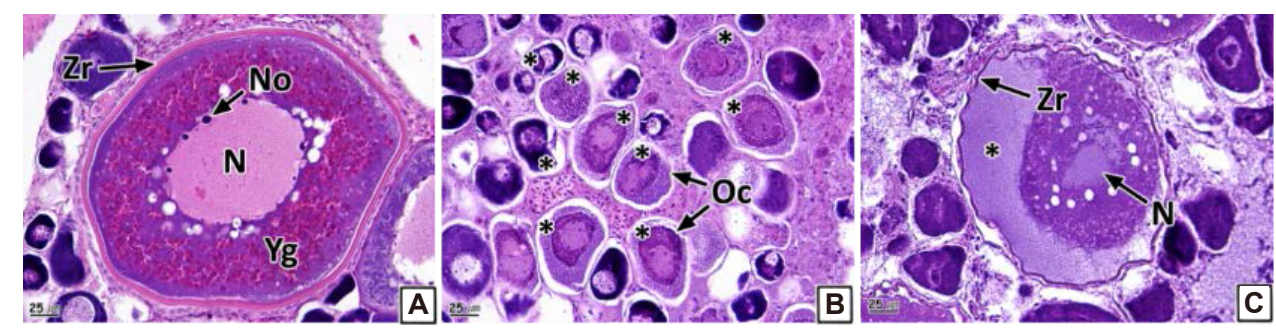

Fig. 2. Photomicrographs of oocytes in the rock bream, Oplegnathus fasciatus. (A) Normal vitellogenic oocyte. (B) and (C) Oocyte atresia. H-E stain. N, nucleus; No, nucleolus; Oc, oocytes; Yg, yolk granules; $\mathrm{Zr}$, zona radiata; ${ }^{*}$, atretic oocytes. 
Table 2. Abnormal type and frequency of gonadal structure in the rock bream, Oplegnathus fasciatus

\begin{tabular}{llll}
\hline \hline \multicolumn{1}{c}{ Abnormal type } & \multicolumn{2}{c}{ Frequency $(\%)$} \\
\hline Ovary & Oocyte atresia (Oa) & 85.34 & $(\mathrm{n}=262 / 307)$ \\
& Ovarian neoplasia (On) & 21.50 & $(\mathrm{n}=66 / 307)$ \\
Scale formation in the ovary (So) & 1.95 & $(\mathrm{n}=6 / 307)$ \\
Oa ${ }^{*}$ On & 19.22 & $(\mathrm{n}=59 / 307)$ \\
& Oa ${ }^{*}$ So & 0.65 & $(\mathrm{n}=2 / 307)$ \\
& On ${ }^{*}$ So & 0.33 & $(\mathrm{n}=1 / 307)$ \\
& Oa ${ }^{*}$ On ${ }^{*}$ So & 0.33 & $(\mathrm{n}=1 / 307)$ \\
\hline Testis & Deformation of testicular lobule and cyst (Dt) & 73.05 & $(\mathrm{n}=103 / 141)$ \\
& Testicular neoplasia (Tn) & 37.59 & $(\mathrm{n}=53 / 141)$ \\
& Scale formation in the testis (St) & 2.13 & $(\mathrm{n}=3 / 141)$ \\
& $\mathrm{Dt}{ }^{*} \mathrm{Tn}$ & 26.95 & $(\mathrm{n}=38 / 141)$ \\
& $\mathrm{Dt}{ }^{*} \mathrm{St}$ & 1.42 & $(\mathrm{n}=2 / 141)$ \\
& $\mathrm{Tn}{ }^{*} \mathrm{St}$ & - & $(\mathrm{n}=0 / 141)$ \\
$\mathrm{Dt}{ }^{*} \mathrm{Tn}{ }^{*} \mathrm{St}$ & - & $(\mathrm{n}=0 / 141)$ \\
\hline
\end{tabular}

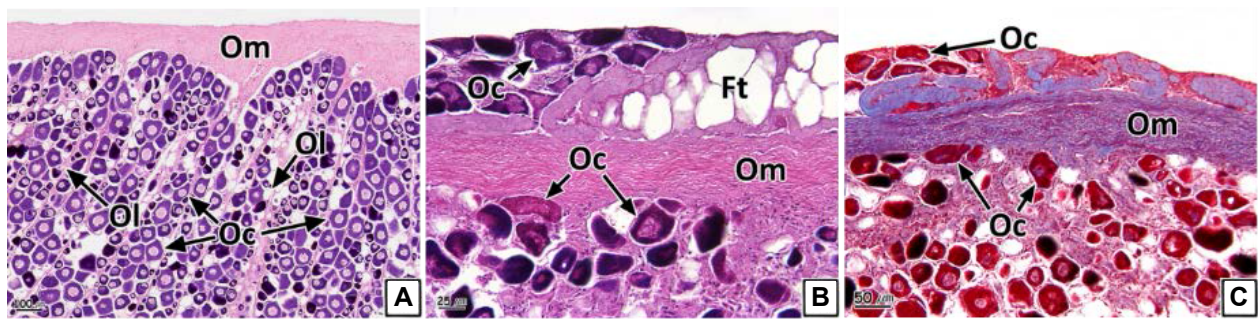

Fig. 3. Photomicrographs of ovary in the rock bream, Oplegnathus fasciatus. (A) Normal ovary. (B) and (C) Ovarian neoplasm. (A) and (B) H-E stain, (C) Masson's trichrome stain. Section showing the formation of numerous oocytes $(\mathrm{Oc})$, connective tissue and fatty tissue $(\mathrm{Ft})$ in the outer ovarian membrane $(\mathrm{Om})$. $\mathrm{Ol}$, ovarian lamella.

seen in the rock bream during the present study were similar to those from these previous studies.

Gonadal neoplasm of aquatic animals has been mainly reported in the form of nodules, tumors, or mixed germ cell-stromal neoplasia from crucian carp, Carassius carassius (Fregeneda-Grandes et al., 2010); softshell clam, Mya arenaria (Barber, 1996) and mussel, Mytilus galloprovincialis (Carballal et al., 2015). These previous studies focused on various chemical pollutants as the cause of these anomalies. However, Spitsbergen et al. (2012) stated that diet and the aquaculture environment were the primary causes of confirmed neoplasia in multiple organs, including gonads, from zebra fishes raised in an aquarium.

\section{Testicular structure abnormality}

\section{1) Deformation of testicular lobule and cyst}

Each testicular lobule and cyst comprising the testis were divided by a thin membrane of connective tissues (Fig. 4A and B). However, part of or the entire membranes of the testicular lobules and cysts of some individuals were disintegrated; thus, we could not discern the form of the individual testicular lobules and cysts (Fig. 4C and D). The prevalence of collapsed testicular lobules and cysts was $73.1 \%$ (Table 2). 


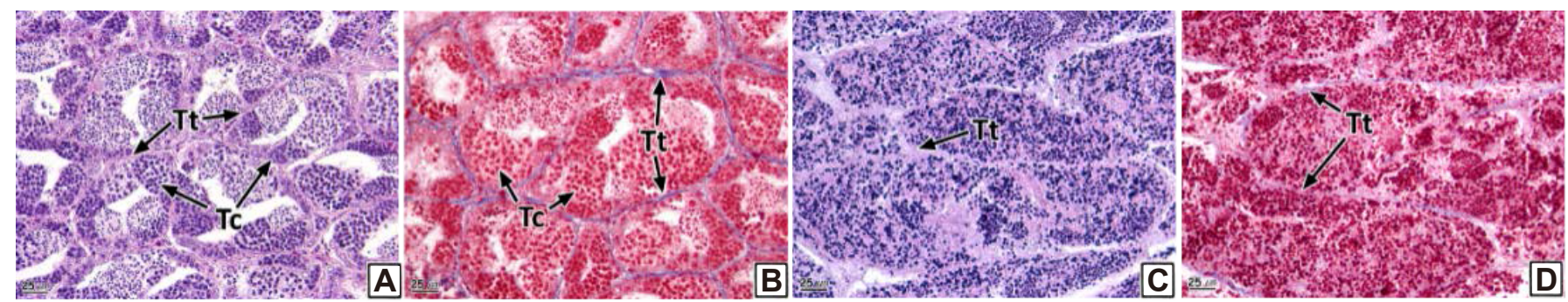

Fig. 4. Photomicrographs of testis in the rock bream, Oplegnathus fasciatus. (A) and (B) Normal testicular lobules (Tt) and cysts (Tc). (C) and (D) Deformation of testicular lobules and cysts. (A) and (C) H-E stain, (B) and (D) Masson's trichrome stain.

\section{2) Testicular neoplasm}

Similar to the ovaries, anatomical neoplasia was not confirmed in the testes. However, in histological analysis, neoplasia was observed in the form of groupings of basophilic sperm combined with connective tissues in the outside of the testicular outer membrane (Fig. 5). Testicular neoplasm was prevalent in $37.6 \%$ of the male samples (Table 2).

The testis of teleosts consist of multiple testicular lobules surrounded by thin connective tissues (Lee \& Huh, 2000; Blazer, 2002). Each testicular lobule retains numerous testicular cysts, and germ cells develop synchronously in the same testicular cyst (Lee et al., 2010). Spermatogenesis in teleosts is controlled by the central nervous system and endocrinological function of Leydig cells and Sertoli cells spread around the testis (Grier, 1981). Therefore, the deformation of testicular lobules and cysts in the rock bream could be determined to be histological evidence of an inability to obtain normal spermatogenesis.

\section{Scale formation in the gonadal cavity}

We also observed the formation of scales inside the gonadal cavity in some individual samples (Fig. 6). The scales showed eosinophilic stainability in the $\mathrm{H}-\mathrm{E}$ stain and the center of the scales turned red and the peripheral parts stained to blue in Masson's trichrome stain (Fig. 6B and C). The prevalence of scale formation in the ovary and testis was $2.0 \%$ and $2.1 \%$ respectively (Table 2).

Scales of teleosts are formed by the hardening of connective tissues in the dermis of the skin (Takashima \& Hibiya, 1995); moreover, vital somatic tissues inside the gonads also consist of connective tissues (Genten et al., 2009). Chemical factors such as EDC's (endocrine disrupting chemicals) affects influence adipogenesis and osteogenesis in mesenchymal stem cells (Bateman et al., 2017). Chemical factors influence the synthesis of collagen, a major component of connective
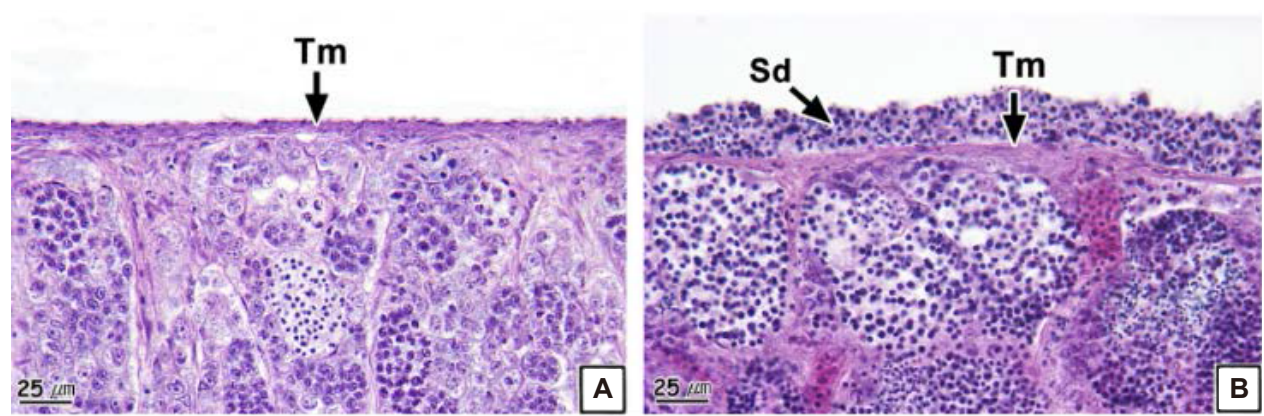

Fig. 5. Photomicrographs of testis in the rock bream, Oplegnathus fasciatus. (A) Normal testis. (B) Testicular neoplasm. H-E stain. Section showing the formation of testicular tissue and spermatids (Sd) in the outer testicular membrane (Tm). 


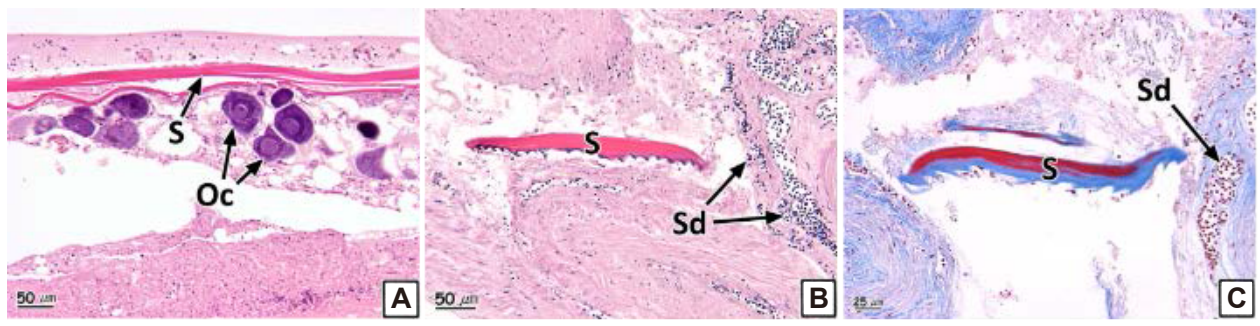

Fig. 6. Photomicrographs of scale (S) formation in the ovary $(A)$ and testis $(B)$ and $(C)$ of the rock bream, Oplegnathus fasciatus. (A) and (B) H-E stain, (C) Masson's trichrome stain. Oc, oocytes; Sd, spermatids.

tissue, in fish such as Salmo gairdneri, Salvelinus fontinalis, Pimephales promrlas, Ictalurus punctatus (Mayer et al., 1977) and Pimephales promelas (Mehrle et al., 1981). In addition, in association with other gonad abnormalities identified in this study, one of the important causes of scale formation in the gonads is considered to be chemicals. Although the formation of scales inside the gonads in rock bream resulted from the disruption of the endocrine system due to chemical factors during the early embryonic stage, especially when connective tissues are differentiated, additional research regarding this topic is required.

\section{Intersexuality}

The overall intersexuality in the rock breams reached $42.2 \%$, being higher in the female samples (49.5\% in females and $26.2 \%$ in males; Fig. 7 ).

The intersex type observed in the gonads was histologically classified into four types (I, II, III, and IV). Type I shows germ cells of the opposite sex spread throughout the connective tissues of the gonadal cavity (Figs. 8A and 9A). Type II is the distribution of germ cells of the opposite sex in the newly formed connective tissues outside the gonad outer membrane (Figs. 8B and 9B). Type III represents the form in which the sperm and oocytes coexist in the connective tissues outside the

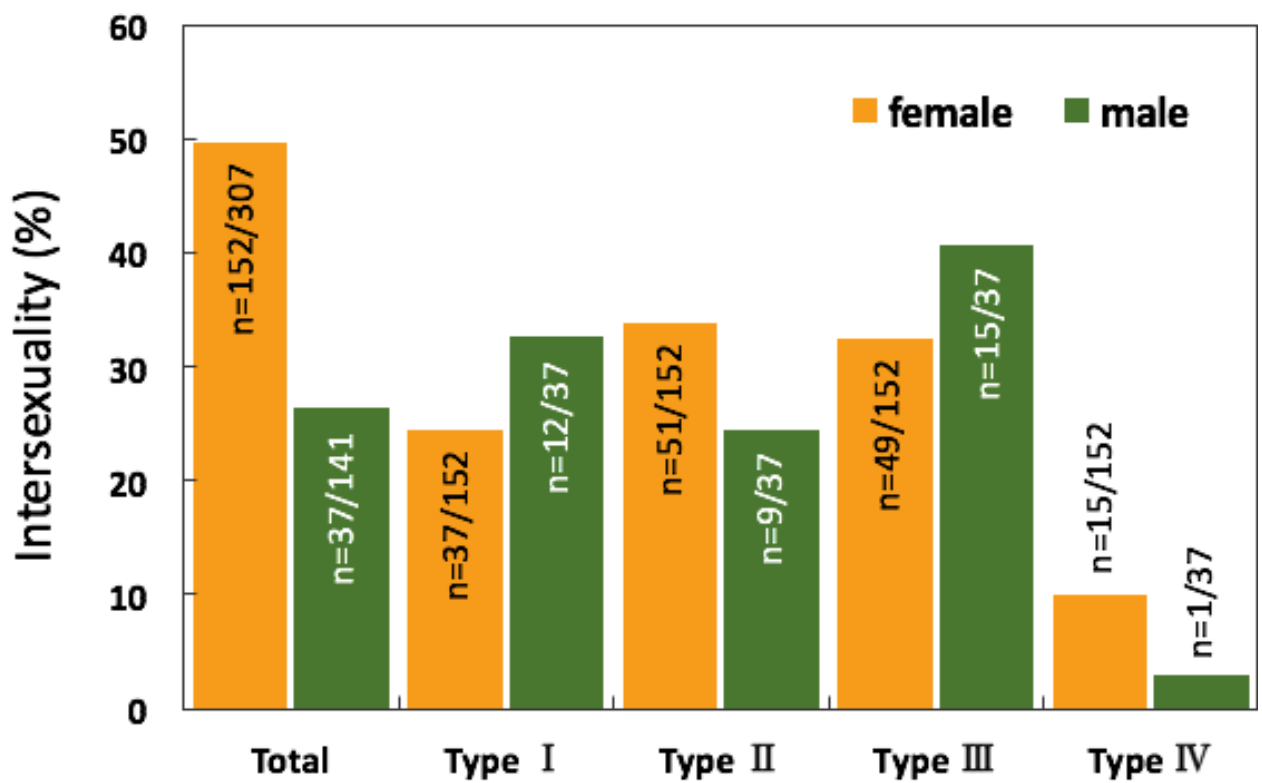

Fig. 7. Intersexuality of the rock bream, Oplegnathus fasciatus. 

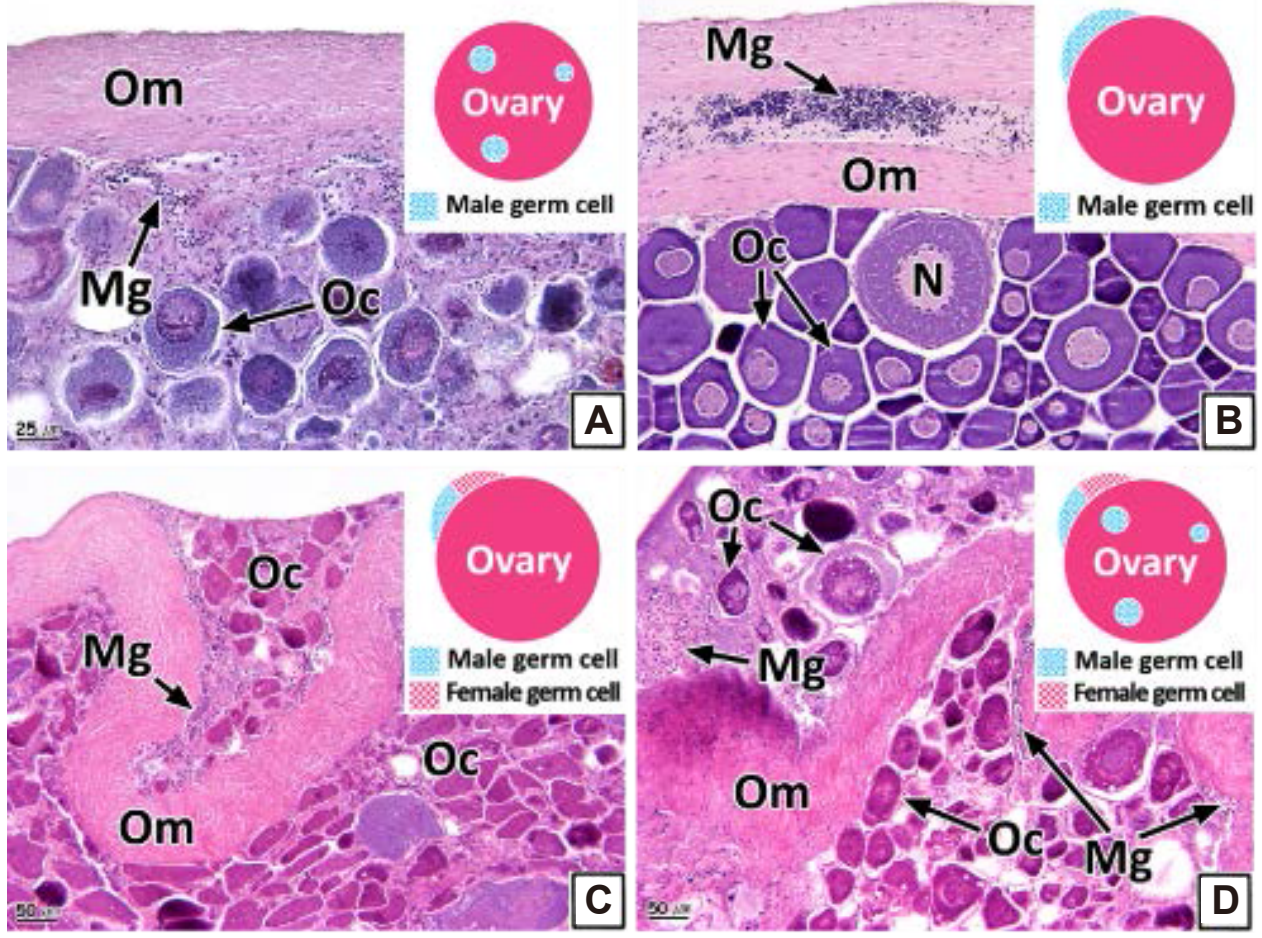

Fig. 8. Schematic diagram and photomicrographs of intersex type in the female rock bream, Oplegnathus fasciatus. (A) Type I. (B) Type II. (C) Type III. (D) Type IV. H-E stain. Mg, male germ cells; N, nucleus; Oc, oocytes; Om, ovarian outer membrane.
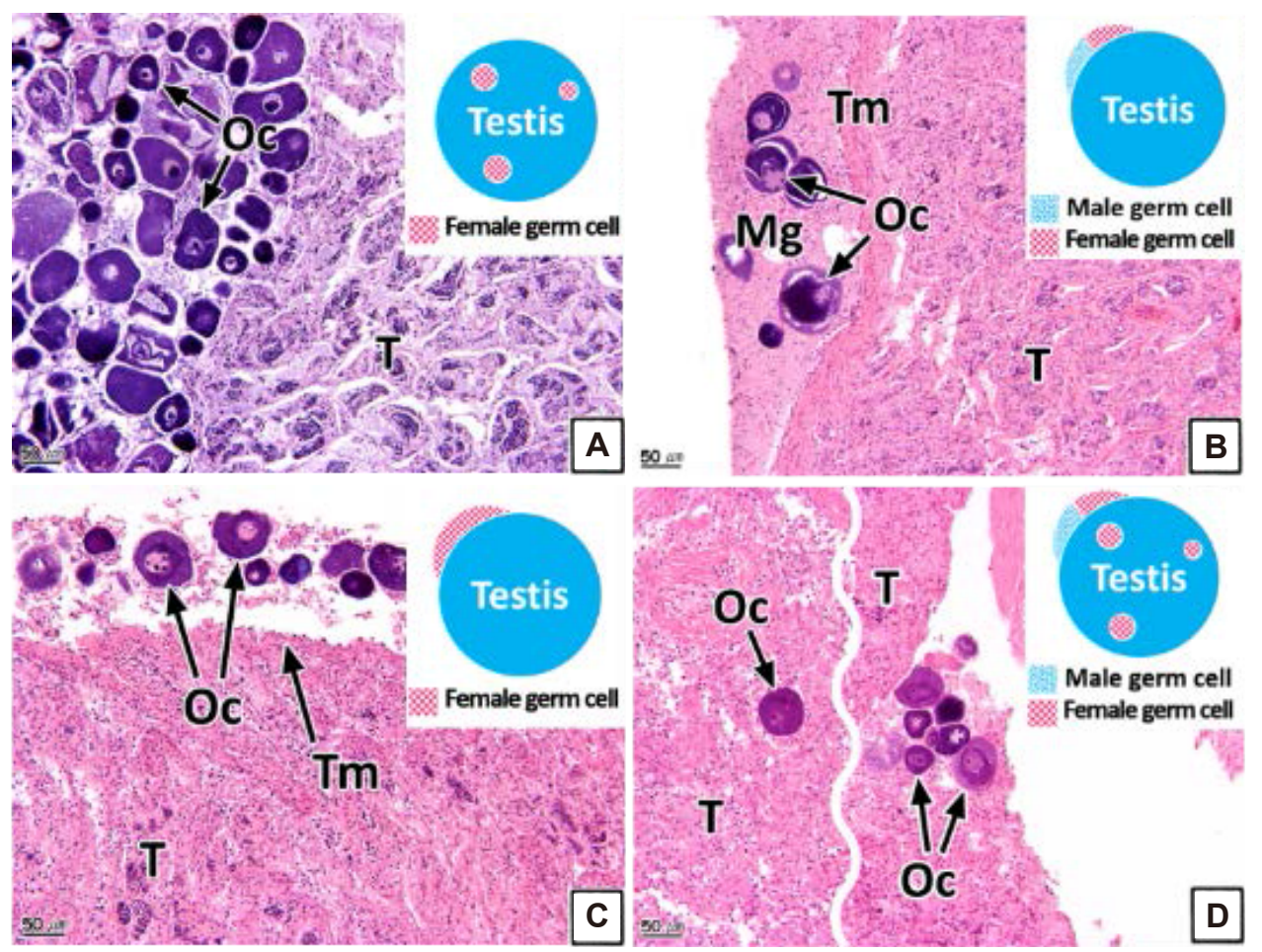

Fig. 9. Schematic diagram and photomicrographs of intersex type in the male rock bream, Oplegnathus fasciatus. (A) Type I. (B) Type II. (C) Type III. (D) Type IV. H-E stain. Mg, male germ cells; Oc, oocytes; T, testis; Tm, testicular outer membrane. 
gonad outer membrane (Figs. 8C and 9C). Type IV is the form in which the sperm and oocytes coexist in connective tissues outside the gonad outer membrane as well as in the gonadal cavity (Figs. $8 \mathrm{D}$ and $9 \mathrm{D})$.

Intersex is one of the pathological sexual abnormalities that manifest due to environmental factors, such as the presence of endocrine-disrupting chemicals or heavy metals (Bortone \& Davis, 1994). Studies of such abnormalities in teleosts have been undertaken in various species including Gambusia affinis and largemouth bass (Drysdale \& Bortone, 1989; Blazer, 2002; Barnhoorn et al., 2010; Lee et al., 2010; Bahamonde et al., 2013; Mankidy et al., 2013).

Two primary causes of intersexuality and structural abnormalities in the gonads of rock bream can be confirmed from the results of the present study. The first cause is the presence of chemical factors such as EDC's in their habitat. The second cause is the chemical components contained in mixed feeds, which are artificially supplied during the early life stages of artificial production of young rock bream. However, more detailed studies are required to ascertain the reasons for intersexuality and gonad structural abnormalities.

\section{REFERENCES}

Bahamonde PA, Munkittrick KR, Martyniuk CJ (2013) Intersex in teleost fish: Are we distinguishing endocrine disruption from natural phenomena? Gen Comp Endocrinol 192:2535 .

Barber BJ (1996) Effects of gonadal neoplasms on oogenesis in softshell clams, Mya arenaria. J Invertebr Pathol 67:161-168.

Barnhoorn IEJ, van Dyk JC, Pieterse GM, Bornman MS (2010) Intersex in feral indigenous freshwater Oreochromis mossambicus, from various parts in the Luvuvhu River, Limpopo Province, South Africa. Ecotoxicol Environ Saf 73:1537-1542.

Bateman ME, Strong AL, McLachlan JA, Burow ME, Bunnell BA (2017) The effects of endocrine disruptors on adipogenesis and osteogenesis in mesenchymal stem cells: A review. Front Endocrinol 7:171.

Blazer VS (2002) Histopathological assessment of gonadal tissue in wild fishes. Fish Physiol Biochem 26:85-101.

Bortone SA, Davis WP (1994) Fish intersexuality as indicator of environmental stress. Bioscience 44:165-172.

Carballal MJ, Barber BJ, Iglesias D, Villalba A (2015) Neoplastic diseases of marine bivalves. J Invertebr Pathol 131:83-106.

Colin N, Porte C, Fernandes D, Barata C, Padrós F, Carrassón M, Monroy M, Cano-Rocabayera O, de Sostoa A, Piña B, Maceda-Veiga A (2016) Ecological relevance of biomarkers in monitoring studies of macro-invertebrates and fish in Mediterranean rivers. Sci Total Environ 540:307323.

Cuevas N, Zorita I, Costa PM, Quincoces I, Larreta J, Franco J (2015) Histopathological indices in sole (Solea solea) and hake (Merluccius merluccius) for implementation of the European Marine Strategy Framework Directive along the Basque continental shelf (SE Bay of Biscay). Mar Pollut Bull 94:185-198.

Drysdale DT, Bortone SA (1989) Laboratory induction of intersexuality in the mosquitofish, Gambusia affinis, using paper mill effluent. Bull Environ Contam Toxicol 43:611-617.

FIRA (Korea Fisheries Resources Agency) (2015) Release discharge of Gyeongsangnam-do, Jeollannam-do of the rock bream, Oplegnathus fasciatus in 2012-2015. 
Fregeneda-Grandes JM, García-Iglesias MJ, Pérez-Martínez C, Aller-Gancedo JM (2010) Mixed germ cell-stromal testicular neoplasia in a crucian carp (Carassius carassius L.): A case report. Bull Eur Assoc Fish Pathol 30:114-119.

Genten F, Terwinghe E, Danguy A (2009) Atlas of Fish Histology. Science, Enfield, NH, pp $1-215$.

Grier HJ (1981) Cellular organization of the testis and spermatogenesis in fishes. Am Zool 21:345357.

Huggett RJ, Kimerle RA, Mehrle PM Jr, Bergman HL (1992) Biomarkers: Biochemical, Physiological and Histological Markers of Anthropogenic Stress. Lewis, Boca Raton, FL, pp $1-347$.

Kim IS, Choi Y, Lee CL, Lee YJ, Kim BJ, Kim JH (2005) Illustrated Book of Korean Fishes. KyoHak, Seoul, Korea, pp 1-613.

Kokokiris L, Ragias V, Athanassopoulou F (2005) Histopathological alterations of gonads in teleosts. J Hell Vet Med Soc 56:138-153.

Lee JS, Huh SH (2000) Reproductive biology of the slimy, Leiognathus nuchalis (Teleostei: Leiognathidae). Korean J Ichthyol 12:192-202.

Lee JS, Kim JW, Park JJ, Ju SM, Park JS, Lee DG, Yun TW, Choi KH, Yoon JH, Eom IC (2010) Sex ratio and intersexuality in coastal fishes near industrial complex of Korea. J Fish Pathol 23:211-219.

Mankidy R, Wiseman S, Ma H, Giesy JP (2013) Biological impact of phthalates. Toxicol Lett 217:50-58.

Mayer FL, Mehrle PM, Schoettger RA (1977) Collagen metabolism in fish exposed to organic chemicals. In: Tubb RA (ed), Recent Advances in Fish Toxicology: A Symposium. U.S. Environmental Protection Agency, Corvallis, OR, pp 31-54.

Mehrle PM, Mayer FL, Buckler DR (1981) Kepone and mirex: Effects on bone development and swim bladder composition in fathead minnows. Trans Am Fish Soc 110:638-643.

National Research Council (1983) Risk Assessment in the Federal Government: Managing the Process. National Academies Press, Washington, DC, pp 1-191.

Pinkney AE, Myers MS, Rutter MA (2017) Histopathology of brown bullhead (Ameiurus nebulosus), smallmouth bass (Micropterus dolomieu), and yellow perch (Perca flavescens) in relation to polychlorinated biphenyl (PCB) contamination in the Hudson River. Sci Total Environ 575:1325-1338.

Schmitt CJ, Hinck JE, Blazer VS, Denslow ND, Dethloff GM, Bartish TM, Coyle JJ, Tillitt DE (2005) Environmental contaminants and biomarker responses in fish from the Rio Grande and its U.S. tributaries: Spatial and temporal trends. Sci Total Environ 350:161-193.

Smolarz K, Hallmann A, Zabrzańska S, Pietrasik A (2017) Elevated gonadal atresia as biomarker of endocrine disruptors: Field and experimental studies using Mytilus trossulus (L.) and 17-alpha ethinylestradiol (EE2). Mar Pollut Bull 120:58-67.

Spitsbergen JM, Buhler DR, Peterson TS (2012) Neoplasia and neoplasm: Associated lesions in laboratory colonies of zebrafish emphasizing key influences of diet and aquaculture system design. ILAR J 53:114-125.

Takashima F, Hibiya T (1995) An Atlas of Fish Histology: Normal and Pathological Features. 2nd ed. Kodansha, Tokyo, Japan, pp 1-195. 
